Journal of Bangladesh Academy of Sciences, Vol. 36, No. 1, 89-96, 2012

\title{
SYNTHESIS AND CHARACTERIZATION OF A THIOCYANATE BRIDGED DINUCLEAR CU(II) COMPLEX CONTAINING MACROCYCLIC LIGAND DERIVED FROM PYRIDINE-2, 6-DICARBOXALDEHYDE AND 1, 2-BIS(2- AMINOETHOXY) ETHANE
}

\author{
MD. MAHBUBUL ALAM*, FAISAL AHMED, ROCKSHANA BEGUM, S. M. \\ MIZANUR RAHMAN ${ }^{1}$, IQBAL AHMED SIDDIQUEY, MOHAMMAD RAZAUL \\ KARIM, AND ISLAM SM SAIFUL \\ Department of Chemistry, Shahjalal University of Science and Technology, Sylhet-3114, \\ Bangladesh
}

\begin{abstract}
The cyclic $(2+2)$ template condensation of pyridine-2,6-dicarboxaldehyde with 1,2-Bis(2aminoethoxy) ethane using $\mathrm{Pb}(\mathrm{SCN})_{2}$ gave dinuclear lead (II) complex, $\mathrm{Pb}_{2} \mathrm{~L}_{1}(\mathrm{SCN})_{4}$, where $\mathrm{L}_{1}$ is a tetra-Schiff-base macrocycle. The transmetallation treatment of $\mathrm{Pb}_{2} \mathrm{~L}_{1}(\mathrm{SCN})_{4}$ with $\mathrm{Cu}\left(\mathrm{ClO}_{4}\right)_{2} \cdot 6 \mathrm{H}_{2} \mathrm{O}$ yield the complex, $\left[\mathrm{Cu}_{2} \mathrm{~L}_{1}(\mathrm{SCN})_{3}\left(\mathrm{ClO}_{4}\right)\right]$ which has been characterized by elemental analysis, IR, ESI-MS spectroscopy and X-ray crystallography. On the basis of spectral data, different geometry of $\mathrm{Cu}^{2+}$ has been suggested.
\end{abstract}

Key words: Macrocyclic complexes, Spectroscopic studies, 1,2-bis(2-aminoethoxy) ethane, X-ray crystallography

\section{INTRODUCTION}

Dinuclear metal complexes in which metal centers are in close proximity are of current interest as model of metalloproteins (Eawards et al. 1992). Macrocyclic ligands are widely recognized as functional molecules that can bring out the full potential of accommodated metal ions. A number of excellent examples of universal ligands such as crown ethers (Gokel et al. 2004), porphyrins (Hambright 1971) and saturated (or unsaturated) macrocyclic polyamines (Kimura 1992, Zhang et al. 1997), their chemical properties and functions as metal complexes have been systematically enhanced by the facile and diverse chemical modification of their macrocyclic frameworks. The study of macrocyclic ligands and their complexes has been a very active area of research interest for many years which continues to expand. Hence, the design and study of well-disposed metal-containing macrocycles with desirable properties still continues to be important. The template condensation reaction lies at the heart of macrocyclic chemistry (Curtis 1968) and have been widely used for synthesis of macrocyclic complexes where,

\footnotetext{
* Corresponding author: <mahbubana-che@sust.edu, flora2289@yahoo.com>.

1 Department of Chemistry, Bangladesh University of Engineering and Technology, Dhaka-1000, Bangladesh.
} 
generally the transition metal ions are used as templating metal agents (Niasari et al. 2006). Macrocyclic complexes find use in DNA recognition and oxidation (Muller et al. 1993) and detecting tumor lesions (Kosmos et al. 1992). Considering these factors, in this paper present authors report the synthesis and characterization of a new type of thiocyanate bridged macrocyclic dinuclear $\mathrm{Cu}$ (II) complex (Fig. 1.). The crystal structure of the complex is also reported.

\section{MATERIALS AND METHODS}

Elemental analysis was carried out at the Instrumental Research Center on JM10 MICROCORDER made by J. Science laboratory Co., Ltd. IR Spectra were recorded on an Excalibur Series JASCO FT/IR 3000MX/UMA250 spectrometer in the range 4000$400 / \mathrm{cm}^{-1}$ as $\mathrm{KBr}$ pellets. NMR spectra were measured on a Bruker Avance ${ }^{\mathrm{III}}-400$ with $\mathrm{CDCl}_{3}$ as solvent. The positive-ion ESI-mass spectrum of complexes was obtained with a Quatttro micro API spectrometer manufactured by Waters. X-ray measurement was performed on a Rigaku Saturn $\mathrm{CCD}$ area detector at $\mathrm{Li}$ was first prepared by condensation pyridine-216-discardox aldehyde with 1,2-bis(2-amino ethony) ethane which was subsequentcy treated with $\mathrm{Pb}(\mathrm{SCN})_{2}$ to yield $\mathrm{pb}_{2} \mathrm{Li}(\mathrm{SCN})_{4}$ by the method as reparted in the literature (Alam et al. 2011). Pyridine-2,6-dicarboxaldehyde and $\mathrm{Pb}_{2} \mathrm{~L}_{1}(\mathrm{SCN})_{4}$ were prepared by method reported by Alam et al. (2011).. All measurements were performed at room temperature $\left(25 \pm 2{ }^{\circ} \mathrm{C}\right)$.

Synthesis of $\left[\mathrm{Cu}_{2} \mathrm{~L}_{1}(\mathrm{SCN})_{3}\left(\mathrm{ClO}_{4}\right)\right]$ : About $150 \mathrm{ml}$ methanol was heated at $60^{\circ} \mathrm{C}$ for 30 minutes to which $0.222 \mathrm{~g}(0.1945 \mathrm{mmol})$ of $\mathrm{Pb}_{2} \mathrm{~L}_{1}(\mathrm{SCN})_{4}$ was added and heating was continued for another 30 minutes. $\mathrm{Cu}\left(\mathrm{ClO}_{4}\right)_{2} \cdot 6 \mathrm{H}_{2} \mathrm{O}(0.144 \mathrm{~g}, 0.39 \mathrm{mmol}$ plus slight excess) was added to the solution. The reaction mixture was refluxed for 2 hours at $70^{\circ} \mathrm{C}$ resulting a green solution. After filtration the solution was concentrated in rotary evaporator until crystallization begun. Recrystallization from acetonitrile and diethyl ether gave an emerald green crystal. Yield $=34 \%$, Calc. for $\mathrm{C}_{29} \mathrm{H}_{34} \mathrm{ClCu}_{2} \mathrm{~N}_{9} \mathrm{O}_{8} \mathrm{~S}_{3}$ : $\mathrm{C}$, 38.90; H, 3.83; N, 14.08\%. Found: C, 38.94; H, 3.81; N, $14.08 \%$. IR (KBr): v(SCN) $2075 / \mathrm{cm}, 2098 / \mathrm{cm}, v(\mathrm{C}=\mathrm{N}) \mathrm{Py} 1589 / \mathrm{cm}, v\left(\mathrm{ClO}_{4}{ }^{-}\right) 1091 / \mathrm{cm}, 813 / \mathrm{cm}(\mathrm{SCN}), 786 / \mathrm{cm}$ (SCN), 667/cm v $\left(\mathrm{ClO}_{4}^{-}\right), 621 / \mathrm{cm} v\left(\mathrm{ClO}_{4}^{-}\right)$.

Crystal structure determination: The block type crystals of complex, $\left[\mathrm{Cu}_{2} \mathrm{~L}_{1}(\mathrm{SCN})_{3}\left(\mathrm{ClO}_{4}\right)\right]$ are so stable in air that the single crystal was mounted in a capillary without coating. Data collection was performed on a Rigaku Saturn CCD area detector with graphite monochromated Mo-K $\alpha$ radiation. Indexing was performed from 0 images that were exposed for 0 seconds. The crystal-to-detector distance was $45.31 \mathrm{~mm}$. The structure was solved by direct methods (Altomare et al. 1994) and expanded using Fourier techniques (Beurskens et al. 1999). The non-hydrogen atoms were refined anisotropically. Hydrogen atoms were refined using the riding model. The final cycle of 
full-matrix least-squares refinement on $\mathrm{F}^{2}$ was based on 9391 observed reflections and 503 variable parameters and converged (largest parameter shift was 0.00 times its esd) with unweighted and weighted agreement factors of:

$$
\begin{aligned}
& \mathrm{R} 1=\sum\|\mathrm{Fo}|-| \mathrm{Fc}\| / \sum|\mathrm{Fo}|=0.0324 \\
& \mathrm{wR}^{2}=\left[\sum\left(\mathrm{w}\left(\mathrm{Fo}^{2}-\mathrm{Fc}^{2}\right)^{2}\right) / \sum \mathrm{w}(\mathrm{Fo} 2) 2\right]^{1 / 2}=0.0742
\end{aligned}
$$

\section{RESULTS AND DISCUSSION}

The blocked type crystalline thiocyanate bridged complex of macrocyclic ligand $\mathrm{L}_{1}$ with $\mathrm{Cu}^{2+}$ was prepared in $34 \%$ yield by the reaction of $\mathrm{Pb}_{2} \mathrm{~L}_{1}(\mathrm{SCN})_{4}$ with an excess of copper perchlorate in methanol solution. Replacement of $\mathrm{Pb}^{2+}$ ion from the macrocycle was effected readily as judged by instantaneous color change on mixing of reactants. The analytical data showed the suggested formula for macrocyclic complex as $\left[\mathrm{Cu}_{2} \mathrm{~L}_{1}(\mathrm{SCN})_{3}\left(\mathrm{ClO}_{4}\right)\right]$, where, $\mathrm{L}_{1}=$ Schiff's base type macrocyclic ligand $\left(\mathrm{C}_{26} \mathrm{H}_{34} \mathrm{~N}_{6} \mathrm{O}_{4}\right)$.

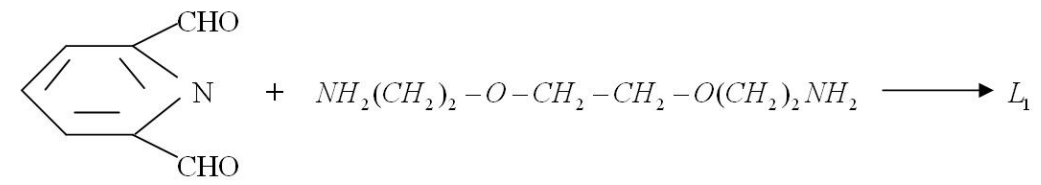

$$
L_{1}+p b(S C N)_{2} \longrightarrow p b_{2} L_{1}(S C N)_{4}
$$

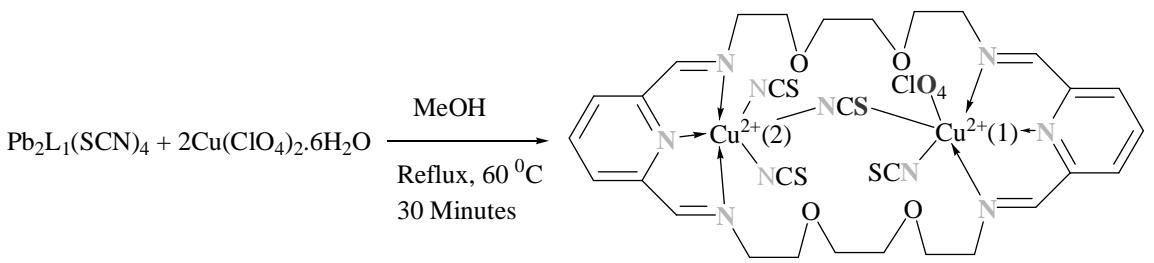

Scheme1. Preparation of $\left[\mathrm{Cu}_{2} \mathrm{~L}_{1}(\mathrm{SCN})_{3}\left(\mathrm{ClO}_{4}\right)\right]$ complex.

The formation of $\left[\mathrm{Cu}_{2} \mathrm{~L}_{1}(\mathrm{SCN})_{3}\left(\mathrm{ClO}_{4}\right)\right]$ complex was confirmed by ESI-MS spectrometry. The data were in good agreement with the formation of macrocyclic frame. Measured and calculated isotope patterns of the complex ion are shown in Fig. 1.

The IR spectra of the complex indicate that the macrocycle has remained unchanged during the metal exchange reaction. There is no absorption at $3200-3400 / \mathrm{cm}$ indicates that no hydrolysis to amine and carbonyl comparend had occurred. Complex $\left[\mathrm{Cu}_{2} \mathrm{~L}_{1}(\mathrm{SCN})_{3}\left(\mathrm{ClO}_{4}\right)\right]$ showed two strong bands at 2098 and $2075 / \mathrm{cm}$ are due to $\mathrm{Cu}-\mathrm{NCS}$ $\mathrm{Cu}$ bridging (Kazuo 2008, Mitchel et al. 1960) mode and Cu-NCS mode, respectively. The strong band 1589 is assigned to $v(\mathrm{C}=\mathrm{N})$ vibration (Drew et al. 1977, Drew et al. 1979). 

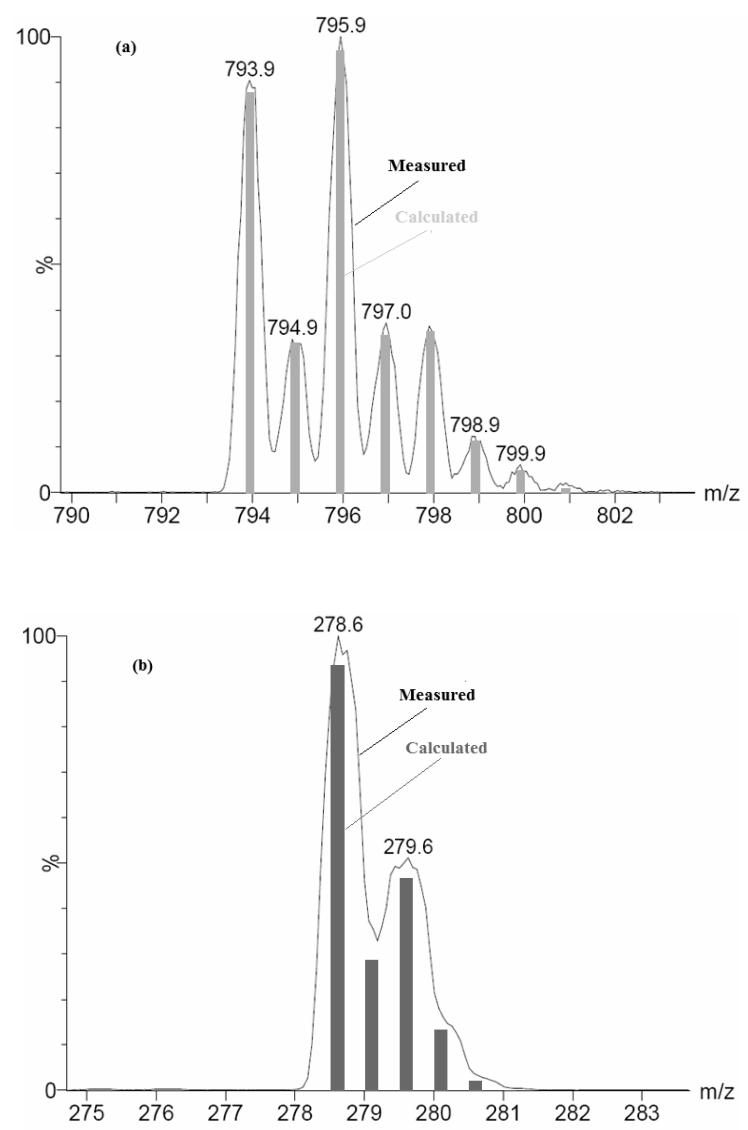

Fig. 1. ESI-MS spectra of (a) $\left[\mathrm{Cu}_{2} \mathrm{~L}_{1}(\mathrm{SCN})_{3}\right]^{+}$and (b) $\left[\mathrm{Cu}_{2} \mathrm{~L}_{1}\right]^{2+}$ ion measured in $\mathrm{CH}_{3} \mathrm{CN}$.

The two strong bands of $\mathrm{ClO}_{4}{ }^{-}$appeared at 1110 and 1090/cm indicated the presence of uni-dentate perchlorate ion (Lewis et al. 1975). The observed bands at 621 and $667 / \mathrm{cm}$ also support the presence of coordinated $\mathrm{ClO}_{4}{ }^{-}$ion (Lewis et al. 1975). Crystal data and details pertaining to the data collection are given Table 1 .

The crystal structure of $\left[\mathrm{Cu}_{2} \mathrm{~L}_{1}(\mathrm{SCN})_{3}\left(\mathrm{ClO}_{4}\right)\right]$ is shown in Fig. 2. The macrocycle $\mathrm{L}_{1}$ binds two copper ions $[\mathrm{Cu}(1)-\mathrm{Cu}(2) 6.064 \AA$ ㄱ] (Drew et al. 1981) into the ring to afford copper pairs in which a $\mathrm{SCN}^{-}$unit bridged. The two metal ions have different coordination geometry. One $\mathrm{Cu}^{2+}(2)$ ion has a five coordination (distorted square pyramidal) geometry attained by imine [Cu(2)-N(4) 2.057(2) $\AA, \mathrm{Cu}(2)-\mathrm{N}(6) 2.064 \AA$ ], pyridine $[\mathrm{Cu}(2)-\mathrm{N}(5) 1.951 \AA]$, bridged thiocynate nitrogen $[\mathrm{Cu}(2)-\mathrm{N}(9) 2.003 \AA]$, and nonbridged thiocyanate nitrogen $[\mathrm{Cu}(2)-\mathrm{N}(8) 1.987 \AA]$. On the other hand $\mathrm{Cu}^{2+}(1)$ ion attained six coordination (octahedral) by imine $[\mathrm{Cu}(1)-\mathrm{N}(1) 2.081 \AA$, $\mathrm{Cu}(1)-\mathrm{N}(3) 2.070$ $\AA]$, pyridine [Cu(1)-N(2) $1.926 \AA]$, nonbridged thiocyanate $[\mathrm{Cu}(1)-\mathrm{N}(7) 1.906 \AA]$, 
bridged thiocyanate sulfur $[\mathrm{Cu}(1)-\mathrm{S}(3) 2.002 \AA]$, and perchlorate oxygen $[\mathrm{Cu}(1)-\mathrm{O}(7)$ $2.657 \AA]$.

Table 1. Crystallographic data and details of the structure determinations for $\left[\mathrm{Cu}_{2} \mathrm{~L}_{1}(\mathrm{SCN})_{3}\right.$ $\left.\left(\mathrm{ClO}_{4}\right)\right]$.

\begin{tabular}{|c|c|}
\hline Empirical formula & $\mathrm{C}_{29} \mathrm{H}_{3} 4 \mathrm{ClCu}_{2} \mathrm{~N}_{9} \mathrm{O}_{8} \mathrm{~S}_{3}$ \\
\hline Formula weight & 895.37 \\
\hline Crystal color, habit & Colorless, prism \\
\hline Crystal dimensions & $0.45 \times 0.44 \times 0.42 \mathrm{~mm}$ \\
\hline Crystal system & Monoclinic \\
\hline Lattice type & Primitive \\
\hline Detector position & $45.31 \mathrm{~mm}$ \\
\hline Pixel size & $0.137 \mathrm{~mm}$ \\
\hline \multirow[t]{5}{*}{ Lattice parameters } & $\alpha=11.8661(16) \AA$ \\
\hline & $\beta=11.5475(16) \AA$ \\
\hline & $\chi=26.930(4) \AA$ \\
\hline & $\beta=93.0340(19)$ o \\
\hline & $V=3684.8(9) \AA^{3}$ \\
\hline Space group & $P 2_{1} / \mathrm{n}$ (Roma \# 14) \\
\hline $\mathrm{Z}$ value & 4 \\
\hline Dcalc & $1.614 \mathrm{~g} / \mathrm{cm}^{3}$ \\
\hline $\mathrm{F}_{000}$ & 1832.00 \\
\hline $\mathrm{m}(\mathrm{MoK} \square)$ & $14.572 / \mathrm{cm}$ \\
\hline Goniometer & Rigaku AFC10 \\
\hline Radiation & $\begin{array}{l}\text { MoK } \square(1=0.71075 \AA) \\
\text { graphite monochromated }\end{array}$ \\
\hline${ }^{2} \mathrm{qmax}$ & $54.9^{\circ}$ \\
\hline \multirow[t]{2}{*}{ No. of reflections measured } & Total: 14573 \\
\hline & Unique: $8332\left(R_{\text {int }}=0.034\right)$ \\
\hline Refinement & Full-matrix least-squares on $\mathrm{F}^{2}$ \\
\hline Function minimized & $\sum \mathrm{w}\left(\mathrm{Fo}^{2}-\mathrm{Fc}^{2}\right)^{2}$ \\
\hline Least squares weights & $1 /\left[0.0003 \mathrm{Fo}^{2}+1.0000 \mathrm{~s}\left(\mathrm{Fo}^{2}\right)\right] /\left(4 \mathrm{Fo}^{2}\right)$ \\
\hline No. observations $(\mathrm{I}>2.00 \mathrm{~s}(\mathrm{I}))$ & 9391 \\
\hline No. variables & 503 \\
\hline Goodness of fit indicator & 1.010 \\
\hline Max shift/error in final cycle & 0.000 \\
\hline Maximum peak in final diff. map & $0.65 \mathrm{e}-/ \AA^{3}$ \\
\hline Minimum peak in final diff. map & $-0.79 \mathrm{e}-/ \AA^{3}$ \\
\hline
\end{tabular}

Concerning bond distances, the copper(II)-imine nitrogen bonds (average 2.068 ) and copper(II)-pyridine nitrogen bonds (average $1.939 \AA$ ) fall well within the range of distances observed for typical copper-nitrogen (Drew et al. 1981) coordination compounds. 


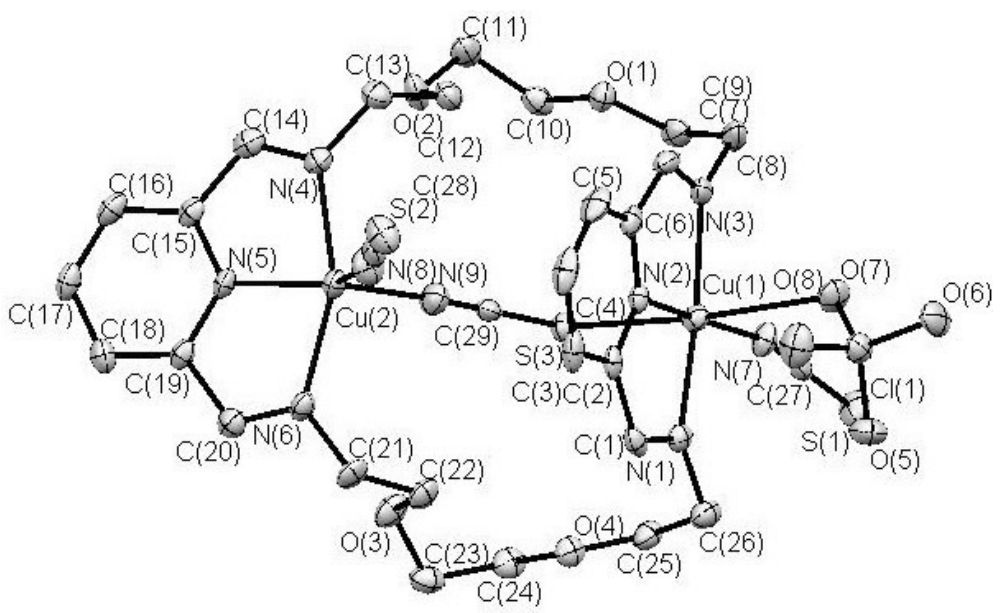

Fig. 2. ORTEP presentation of $\left[\mathrm{Cu}_{2} \mathrm{~L}_{1}(\mathrm{SCN})_{3}\left(\mathrm{ClO}_{4}\right)\right]$ complex.

The perchlorate ion is weakly coordinated to $\mathrm{Cu}(1)$ through a single oxygen atom with separation (Lewis et al. 1975) of $2.657 \AA$ fall within the range 2.56 to $2.83 \AA$. The bond distance between copper-thiocynate bridged nitrogen $[\mathrm{Cu}(2)-\mathrm{N}(9) 2.003 \AA]$ is slightly longer than copper-non bridged thiocyanate nitrogen bond (average $1.945 \AA$ ). Again the C-N bond distance $[\mathrm{C}(29)-\mathrm{N}(9) 1.167 \AA]$ in bridging thiocyanate group slight longer than that in nonbridged mode [C(27)-N(7) $1.161 \AA$ or $\mathrm{C}(28)-\mathrm{N}(8) 1.161 \AA]$. Both of these variations in bond distances confirm bridging of one $\mathrm{SCN}^{-}$unit. The selected bond lengths and bond angles are listed in Tables 2 and 3, respectively.

Table 2. Selected bond lengths $(\AA)$ for $\left[\mathrm{Cu}_{2} \mathrm{~L}_{1}(\mathrm{SCN})_{3}\left(\mathrm{ClO}_{4}\right)\right]$.

\begin{tabular}{lrlrll}
\hline $\mathrm{Cu}(1)-\mathrm{N}(1)$ & $2.081(2)$ & $\mathrm{Cu}(1)-\mathrm{S}(3)$ & $2.002(2)$ & $\mathrm{Cu}(2)-\mathrm{N}(4)$ & $2.057(2)$ \\
$\mathrm{Cu}(1)-\mathrm{N}(2)$ & $1.926(19)$ & $\mathrm{Cu}(2)-\mathrm{N}(5)$ & $1.951(19)$ & $\mathrm{N}(7)-\mathrm{C}(27)$ & $1.161(3)$ \\
$\mathrm{Cu}(1)-\mathrm{N}(3)$ & $2.070(19)$ & $\mathrm{Cu}(2)-\mathrm{N}(6)$ & $2.064(19)$ & $\mathrm{N}(8)-\mathrm{C}(28)$ & $1.161(3)$ \\
$\mathrm{Cu}(1)-\mathrm{N}(7)$ & $1.906(2)$ & $\mathrm{Cu}(2)-\mathrm{N}(8)$ & $1.987(2)$ & $\mathrm{N}(9)-\mathrm{C}(29)$ & $1.167(3)$ \\
$\mathrm{Cu}(1)-\mathrm{O}(7)$ & $2.657(19)$ & $\mathrm{Cu}(2)-\mathrm{N}(9)$ & $2.003(2)$ & & \\
\hline
\end{tabular}

Table 3. Selected bond angles $(\AA)$ for $\left[\mathrm{Cu}_{2} \mathrm{~L}_{1}(\mathrm{SCN})_{3}\left(\mathrm{ClO}_{4}\right)\right]$.

\begin{tabular}{lrlllr}
\hline $\mathrm{N}(1)-\mathrm{Cu}(1)-\mathrm{N}(2)$ & $78.91(8)$ & $\mathrm{N}(1)-\mathrm{Cu}(1)-\mathrm{N}(3)$ & $156.47(8)$ & $\mathrm{N}(5)-\mathrm{Cu}(2)-\mathrm{N}(6)$ & $78.41(8)$ \\
$\mathrm{N}(1)-\mathrm{Cu}(1)-\mathrm{N}(7)$ & $99.83(8)$ & $\mathrm{N}(2)-\mathrm{Cu}(1)-\mathrm{N}(3)$ & $78.66(8)$ & $\mathrm{N}(5)-\mathrm{Cu}(2)-\mathrm{N}(9)$ & $121.79(8)$ \\
$\mathrm{N}(2)-\mathrm{Cu}(1)-\mathrm{N}(7)$ & $172.48(8)$ & $\mathrm{N}(3)-\mathrm{Cu}(1)-\mathrm{N}(7)$ & $101.47(8)$ & $\mathrm{N}(6)-\mathrm{Cu}(2)-\mathrm{N}(9)$ & $97.39(8)$ \\
$\mathrm{O}(7)-\mathrm{Cu}(1)-\mathrm{S}(3)$ & $172.28(8)$ & $\mathrm{N}(7)-\mathrm{Cu}(1)-\mathrm{S}(3)$ & $89.40(8)$ & $\mathrm{N}(5)-\mathrm{Cu}(2)-\mathrm{N}(8)$ & $128.75(8)$ \\
$\mathrm{N}(4)-\mathrm{Cu}(2)-\mathrm{N}(5)$ & $78.59(8)$ & $\mathrm{N}(4)-\mathrm{Cu}(2)-\mathrm{N}(6)$ & $156.90(8)$ & $\mathrm{N}(6)-\mathrm{Cu}(2)-\mathrm{N}(8)$ & $97.85(8)$ \\
$\mathrm{N}(4)-\mathrm{Cu}(2)-\mathrm{N}(8)$ & $94.79(8)$ & $\mathrm{N}(4)-\mathrm{Cu}(2)-\mathrm{N}(6)$ & $156.90(8)$ & $\mathrm{N}(8)-\mathrm{Cu}(2)-\mathrm{N}(9)$ & $109.42(9)$ \\
\hline
\end{tabular}




\section{CONCLUSIONS}

The macrocyclic ligand $\mathrm{L}_{1}$ showed di-nucleating properties toward $\mathrm{Cu}^{2+}$. Elemental analysis and mass spectra data confirm the formation of macrocyclic complex $\left[\mathrm{Cu}_{2} \mathrm{~L}_{1}(\mathrm{SCN})_{3}\left(\mathrm{ClO}_{4}\right)\right]$. Both infrared and X-ray crystallographic data have confirmed the octahedral geometry of one $\mathrm{Cu}^{2+}(1)$, while distorted square pyramidal for the other $\mathrm{Cu}^{2+}(2)$. Perchlorate ion employed to attach as a coordination site rather than its usual counter ionic nature. One of the thiocyanate was found as a bridging ligand between two $\mathrm{Cu}^{2+}$ while the other two are monodentate through nitrogen coordination to different $\mathrm{Cu}^{2+}$.

\section{AKNOWLEDGEMENTS}

Authors thank Professor Dr. Eiji Asato, Department of Chemistry, University of the Ryukyus, Okinawa, Japan for his kind permission to conduct all the measurements. They are grateful to Mr. Gima Shin-Ichi and Mr. Yuto Teruya for their direct help to measure IR and ESI-MS. They also thank to Dr. Satoshi Takara for his technical support.

\section{SUPPLEMENTARY INFORMATIONS}

Crystallographic data have been deposited with the Cambridge Crystallographic Data Centre (CCDC). Copies can be obtained free of charge via www.ccdc.cam.ac.uk/ or from the CCDC, 12 Union Road, Cambridge CB2 1EZ, UK (fax: +44 (0)1223 762911 or email: deposit@ccdc.cam.ac.uk), quoting the deposition numbers CCDC 826014 $\left(\left[\mathrm{Cu}_{2} \mathrm{~L}_{1}(\mathrm{SCN})_{3}\left(\mathrm{ClO}_{4}\right)\right]\right)$.

\section{REFERENCES}

Alam, M. M., R. Begum, S. M. M. Rahman and S. M. S. Islam. 2011. Synthesis, Spectroscopic and Electrochemical Studies of Mononuclear Fe(II) and Ni(II) Complexes Containing a Macrocyclic Ligand Derived from Pyridine-2, 6-dicarboxaldehyde and 1, 2-Bis(2aminoethoxy) Ethane. J. Sci. Res. 3(3): 609-617.

Altomare, A., G. Cascarano, C. Giacovazzo, A. Guagliardi, M. Burla, G. Polidori and M. Camalli. 1994. SIRPOW.92 - a program for automatic solution of crystal structures by direct methods optimized for powder data, J. Appl. Cryst. 27: 435-436.

Beurskens, P. T., G. Admiraal, G. Beurskens, W. P. Bosman, R. de. Gelder, R. Israel, and J. M. M. Smits. 1999. The DIRDIF-99 program system, Technical Report of the Crystallography Laboratory, University of Nijmegen, the Netherlands.

Curtis, N. F. 1968. Macrocyclic coordination compounds formed by condensation of metal-amine complexes with aliphatic carbonyl compounds. Coord. Chem. Rev. 3: 3-47.

Drew, M. G. B., A. H. Bin Othman, S. G. McFall, P. D. A. Mcllory and S. M. Nelson 1977. Sevenco-ordination in metal complexes of quinquedentate macrocyclic ligands. Part 7. Synthesis and properties of some manganese (II), iron (III), Zinc (II), and cadmium (II) complexes of an $\mathrm{N}_{3} \mathrm{O}_{2}$ macrocycle and the crystal and molecular structure of 22,13-dimethyl-6,9-dioxa3,12,18-triazabicyclo[12.3.1]octadeca-1(18),2,12,14,16-pentane \}di- isothiocyanatomanganese (II). J.C.S. Dalton, 1173. 
Drew, M. G. B., A. Rodgers, M. McCann and S. M. Nelson. 1979. Template synthesis of a bimetallic complex of a 30-membered decadentate macrocyclic ligand: the crystal and molecular structure of a lead (II) complex. J.C.S. Chem. Comm. 415.

Drew, M. G. B., M. McCann, and S. M. Nelson. 1981. Bi-copper(I) and bi-copper(II) complexes of a 30-membered macrocyclic ligand: the inclusion of substrate molecules and the crystal and molecular structures of a $\mu$-hydroxo- and a $\mu$-imidazolato-complex. J.C.S. Dalton 9: 18681878.

Gokel, G. W., W. M. Leevy and M. E. Weber. 2004. Crown Ethers: Sensors for Ions and Molecular Scaffolds for Materials and Biological Models. Chem. Rev. 104: 2723-2750.

Hambright, P. 1971.The coordination chemistry of metalloporphyrins, Coord. Chem. Rev. 6: 247268.

Kimura, E. 1992. Macrocyclic polyamines with intelligent functions. Tetrahedron 48: 6175- 6217.

Kosmos, C., D.Snook, C. S.Gooden, N. S.Courtenay Luck, M. J.McCalla, C. F. Meares and A. A. Epenetos. 1992. Development of Humoral Immune Responses against a Macrocyclic Chelating Agent (DOTA) in Cancer Patients Receiving Radioimmunoconjugates for Imaging and Therapy. Cancer Research 52: 904-911.

Lewis, D. L., E. D. Estes and D. J. Hodgson. 1975. The infrared spectra of coordinated perchlorates. J. Cryst. Mol. Struct. 5: 67.

Mitchel, P. C. H. and R. J. P. Williams. 1960. The infrared spectra and general properties of inorganic thiocyanates, J. Chem. Soc. 1912-1918.

Muller, J. G., X. Chen, A. C. Dadiz, S. E. Rokita, and C. J. Burrows. 1993. Macrocyclic nickel complexes in DNA recognition and oxidation, Pure Appl. Chem., 65: 545.

Nakamoto, K. 2008. Infrared and Raman Spectra of Inorganic and Coordination Compounds. Part B. Sixth Edition. A John Wiley \& Sons, Inc.

Niasari, M. S. and Davar F. 2006. In situ one-pot template synthesis (IOPTS) and characterization of copper(II) complexes of 14-membered hexaaza macrocyclic ligand "3,10-dialkyl-dibenzo1,3,5,8,10,12-hexaazacyclotetradecane". Inorg. Chem. Commun. 9: 175-179.

Zhang H. H., J. S. Bradshaw and R. M. Izatt. 1997. Enantiomeric Recognition of Amine Compounds by Chiral Macrocyclic Receptors. Chem. Rev. 97: 3313-3361.

(Received revised manuscript on 7 February, 2012) 